Horses at Work 



\section{Horses at Work}

HARNESSING PaWER IN INDUSTRIAL AMERICA

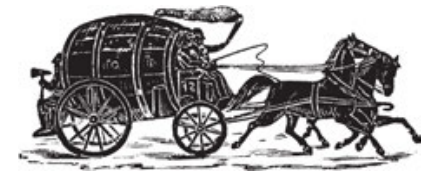

ANN NORTON GREENE

Harvard University Press

Cambridge, Massachusetts $\star$ London, England $\star 2008$ 
Copyright (C) 2008 by the President and Fellows of Harvard College All rights reserved

Printed in the United States of America

Library of Congress Cataloging-in-Publication Data

Greene, Ann Norton, 1952-

Horses at work : harnessing power in industrial America /

Ann Norton Greene.-1st ed.

p. $\mathrm{cm}$.

Includes bibliographical references and index.

ISBN 978-0-674-03129-6 (cloth : alk. paper)

1. Draft horses-United States-History-19th century.

2. Working animals - United States-History-19th century.

I. Title.

SF311.3.U6G68 2008

636.1'0886097309034-dc22 2008014745 
For Bob, Liz, and Andy 
